\title{
APOA4 Gene
}

National Cancer Institute

\section{Source}

National Cancer Institute. APOA4 Gene. NCI Thesaurus. Code C116603.

This gene is involved in the transport of chylomicrons and very low density lipoproteins. 